\title{
Pola Asuh Keluarga Kristen Terhadap Pertumbuhan Iman Anak
}

\author{
Mangiring Tua Togatorop, ${ }^{* 1}$ Septerianus Waruwu, ${ }^{2}$ David Martinus Gulo ${ }^{3}$ \\ Prodi Teologi, STT Real Batam \\ Prodi Teologi, STT Real Batam \\ Prodi Teologi, STT Real Batam \\ timotius_simatupang@yahoo.com
}

\begin{abstract}
Parenting Christian family plays a role in the growth of children's faith from an early age, there is a wrong understanding of the concepts and practices of teaching the growth of children's faith. Christian parents are expected to have an understanding concept of parenting in the family in building their children's faith or education in order to have better collar faith growth. Parenting Christian families play a role in the growth of faith since children. The development of faith through family worship, reading the Word of God together, reading spiritual books and praying together has a great influence and must be done since children. In Deuteronomy 6 it is emphasized how important the role of parents is to instill Christian faith in their children at all times and opportunities. Parents must convey God's commands to their children when they are at home, on daily trips, while lying in bed as well as when they wake up. With an understanding of the true word of God, children will have a strong foundation that will enable them to stand as a firm building of God and also be able to reveal their spiritual life. Parenting Christian families play a role in the growth of children's faith. The development of faith through family worship, reading the Word of God together, reading spiritual books and praying together has a great influence and must be done from an early age. Parenting patterns of Christian families who practice the teachings of the faith must continue to be developed through communication in the daily family. The experience of a parent's relationship with God can be shared with children.
\end{abstract}

Keywords: Parenting, Family, Christianity, Growth, Faith

\begin{abstract}
Abstrak
Pola asuh keluarga Kristen sangat memainkan peranan dalam pertumbuhan iman anak-anak sejak usia dini, adanya pemahaman yang keliru mengenai konsep dan pelaksanaan pengajaran pertumbuhan iman anak. orangtua Kristen diharapkan memiliki konsep pemahaman mengenai pola asuh dalam keluarga dalam membangun iman ataupun pendidikan anaknya supaya memiliki pertumbuhan iman kerah yang lebih baik. Pola asuh keluarga Kristen sangat memainkan peranan dalam pertumbuhan iman sejak anak-anak. Perkembangan iman melalui ibadah keluarga, pembacaan Firman Tuhan bersama-sama, pembacaan buku-buku rohani dan doa bersama sangat besar pengaruhnya dan harus dilakukan sejak anak-anak. Dalam Ulangan 6 ditegaskan betapa pentingnya peranan orangtua untuk menanamkan iman Kristen kepada anak-anaknya setiap masa dan kesempatan. Orangtua harus menyampaikan perintah-perintah Tuhan kepada anak-anak ketika mereka berada dirumah, didalam perjalanan sehari-hari, saat berbaring ditempat tidur mahupun saat bangun. Anak-anak akan memiliki fondasi yang kuat dan memampukannya untuk berdiri sebagai bangunan Allah yang kokoh yaitu dengan pemahaman firman Tuhan yang benar dan juga anak akan hidup dalam kerohanian. Pola asuh keluarga Kristen sangat berperanan dalam pertumbuhan iman anak-anak. Perkembangan iman melalui ibadah keluarga, pembacaan Firman Tuhan bersama-sama, pembacaan buku-buku rohani dan doa bersama sangat besar pengaruhnya
\end{abstract}


dan harus dilakukan sejak usia dini. Pola asuh keluarga Kristen yang mengamalkan pengajaran keimanan harus terus dikembangkan melalui komunikasi dalam keluarga sehari-hari. Pengalaman hubungan orangtua bersama Tuhan dapat dibagikan kepada anak-anak.

Kata kunci: Pola Asuh, Keluarga, Kristen, Pertumbuhan, Iman

\section{PENDAHULUAN}

Pertumbuhan iman Kristen adalah merupakan salah satu harapan dan tujuan di dalam pelayanan gereja, maka setiap orang yang percaya diharapkan dapat bertumbuh dan menjadi matang dalam hidup kerohanian. Tidak ada iman tanpa sebuah proses ddan waktu. Membahas tentang iman tentunya dapat dilihat dari kehidupan dan kepribadian Abraham sebagai bapak orang beriman seperti yang dituliskan oleh Fredy Simanjuntak, Abraham mengalami dua tingkatan iman. Yang pertama adalah menerima dan menunggu dengan sabar. Yang kedua adalah menuntut Allah agar menepati janji-Nya (Kejadian 12,15). ${ }^{1}$ Dengan kata lain Abraham dalam imannya pun mengalami proses baik pasang atau surut dalam hal kerohanian. Namun pada akhirnya Abraham Allah sebut sebagai rujukan iman dari Perjanjian Lama sampai kepada Perjanjian Baru karena ia tidak berhenti dalam proses pertumbuhan iman tersebut. Pertumbuhan iman anak dapat diartikan sebagai bertumbuh secara rohani, iaitu untuk menjadi serupa dan segambar dengan Kristus yang menjadi fokus utama kehidupan orang percaya. Kematangan yang dimaksudkan ialah pemahaman Alkitab, doa, ibadah, karakter, pelayanan pribadi, dan persekutuan dengan orang-orang percaya. Pengenalan secara pribadi kepada Tuhan akan menolong orang-orang percaya untuk menjadi teladan dan seterusnya dapat memimpin dan memberi pengertian kepada orang lain akan tanggung jawabnya sebagai anak-anak Allah dan taat pada apa yang telah ditetapkan oleh Allah baik sekarang mahupun di masa akan datang.

Pertumbuhan iman anak sebaiknya dimulai sejak usia dini. Sejak usia dini bererti dimulai sejak anak baru lahir. Sejak lahir orang tua boleh mendedahkan anak-anak kepada lagu pujian dan penyembahan dalam bentuk audio atau video. Anak-anak yang memulai persekolahan, sudah mulai diajarkan membaca Alkitab, pergi ke Sekolah Minggu, diajak mengikuti ibadah, dan pelajaran-pelajaran mengenai agama. Pendidikan agama yang diberikan orang tua ini selaras dengan firman Tuhan dalam kitab Ulangan 6:6-7 bahwa orang tua memiliki peranan penting dalam mendidik anak dan ini merupakan perintah Allah. Di dalam Perjanijian baru juga ada ditekankan dalam Efesus 6:4 pentingnya didikan, ajaran dan nasehat orang tua bagi anak.

Yesus juga memberikan teladan dalam hal ini ketika ada anak yang diusir oleh para murid ketika ingin mendekati Yesus. Dalam Markus 10 : 14 Yesus marah kepada muridnya karena menghalang-halangi anak-anak untuk datang kepada-Nya. Bahkan Yesus menyatakan bahwa tempat anak-anak yang seperti itu lebih tinggi dari para murid dan

\footnotetext{
${ }^{1}$ Fredy Simanjuntak, "MENGUAK RAHASIA PRIBADI ABRAHAM ATAS KUALITAS KEIMANANNYA PADA ALLAH BAPA,” Real Didache 1, no. 2 (April 16, 2016): 73-94, https://doi.org/10.31227/osf.io/43fj7.
} 
Yesus memberi janji bahwa merekalah (anak-anak) sebagai pemilik Kerajaan Allah. Di mata Tuhan Yesus, anak-anak sangat berharga. Tuhan Yesus memberi perhatian, waktu dan kasih-Nya kepada anak-anak untuk berkomunikasi dengan-Nya. Anak-anak adalah generasi yang akan meneruskan pengkhabarkan Injil-Nya di muka bumi ini.

S. Freud dan H. Erikson dalam Gunarsa mengatakan bahwa Anak harus memperoleh dasar-dasar yang baik pada masa-masa permulaan dari kehidupan anak, supaya kelak setelah dewasa tidak mengalami gangguan emosional atau gangguan kepribadian, oleh karena itu pentingnya pendidikan bagi anak usia dini termasuk usia anak sekolah rendah. ${ }^{2}$ Anak yang sering dididik dalam kekerasan, akan menjadikan anak juga bersikap emosional. Kepribadian yang cenderung emosional akan menguasai kehidupannya dan dapat dilihat ketika menghadapi sesuatu permasalahan. Ia akan cenderung bersikap memaksa agar kehendaknya dipenuhi, pemarah atau pelbagai sikap buruk lainnya. Karena itu sudah semestinya sebagai orangtua, wajib untuk meletakkan dasar sikap emosi dengan iman percaya yang kuat, mengasihi, serta diberikan teladan yang baik sesuai Firman Allah.

Secara umum, ciri-ciri anak tidak terlepas dari segi jasmani, mental, sosial, dan kerohanian; usia sepuluh tahun merupakan titik permulaan perubahan dalam kehidupan seorang anak. Sebelum ia mencapai usia ini, ia dianggap sebagai seorang anak kecil yang berada dibawah pengawasan yang tetap. Tetapi apabila anak-anak yang telah mencapai umur sepuluh tahun, tidak lagi dianggap sebagai anak-anak kecil. Ini dapat dilihat dari segi perbedaan jasmani yang jelas antara anak lelaki dan anak perempuan. Ciri-ciri umum untuk masa ini adalah kesehatannya rata-rata baik sekali; kegiatannya lebih banyak dan lebih beraneka ragam daripada sebelum maupun sudah usia ini; ia mempunyai tenaga dan tidak mudah berasa penat. Fikiranya sangat tajam, dan ia lebih tahan terhadap udara dingin, bahaya, kecelakaan, maupun terhadap pencobaan. ${ }^{3}$ Pola asuh keluarga Kristen yang mengamalkan pengajaran keimanan ini harus terus dikembangkan melalui komunikasi dalam keluarga sehari-hari. Pengalaman hubungan orangtua bersama Tuhan dapat dibagikan kepada anak-anak. Cara hidup yang salah dari orangtua dapat menghapuskan seluruh ajaran yang telah diberikan kepada anak. Contohnya pengajaran kasih kepada sesama akan menjadi sia-sia jika anak-anak melihat orangtuanya sendiri tidak mengamalkan kasih malah sebaliknya. Begitu juga pengajaran tentang memaafkan akan menjadi sia-sia jika anak melihat diantara anggota keluarga sering mendendam, tidak ada sopan santun dan tidak terbiasa meminta maaf dan memaafkan. Sia-sia saja orangtua memperkenalkan kepada anak tentang kasih sebagai hukum yang paling utama dalam pengajaran orang Kristian, jika tindakan menunjukkan mereka tidak menunjukkan demikian.

Sikap dan perilaku orangtua yang lebih mengutamakan status sosial akan merusakkan konsep kasih yang telah diajarkan kepada anak-anak. Orangtua juga harus

\footnotetext{
${ }^{2}$ Singgih D Gunarsa, Psikologi Perkembangan Anak Dan Remaja (Jakarta: BPK Gunung Mulia, 1991).26

${ }^{3}$ Myer Pearlman, Penyelidikan Anak (Malang: Gandum Mas, 1940).41
} 
sadar bahwa didalam keluarga, jati diri anak akan dibentuk. Bila anak-anak banyak dikritik, dibanding-bandingkan dengan orang lain dan diremehkan serta dilabel sebagai anak yang tidak akan berjaya di masa depannya, maka anakpun akan memiliki jati diri bahwa ia akan gagal. Selain tidak percaya diri, anak akan menjadi seorang yang sulit mempercayai kasih Tuhan kerana anak tidak dapat merasa kasih itu sendiri.

Setiap orangtua seharusnya memikirkan pola asuh mereka untuk mengasihi dan mendidik anak sebelum mereka memiliki anak. Bila kedua orangtua bekerja, mereka harus memikirkan secara serius untuk menentukan pengasuh yang tepat bagi anak dengan mempertimbangkan bahawa tahun-tahun pertama kehidupan anak sangat menentukan perkembangan kepribadian anak. Selain kesibukan dalam pekerjaan, keluarga juga harus melihat kesibukan di gereja. Setiap keluarga harus menyedari bahawa pelayanan gerejawi bukanlah satu-satunya bentuk pelayanan kepada Tuhan. Firman Tuhan sendiri mengajarkan bahwa seorang anak yang mengerjakan pekerjaannya dengan sungguh-sungguh untuk menyenangkan hati Tuhan, mereka telah melakukan kehendak Allah.

\section{METODE}

Penelitian ini ditulis dengan menggunakan metode penelitian Deskriptif kualitatif. Penelitian ini dimulai dengan menyusun asumsi dasar dan aturan berpikir yang akan digunakan dalam penelitian. Dalam pengumpulan dan pengolahan data asumsi dan aturan berpiki diterapkan secara teratun untuk dapat memberikan penjelasan dan pendapat berupa pengumpulan data dan penyusuan data. Fenomena dengan aturan bepikir ilmiah yang diterapkan secara sistematis dijelaskan dengan hasil analisi dan penafsiran tanpa menggunakan model kuantitatif. Penjelasannya dalam penelitian ini lebih menekan pada kekuatan analisis data pada sumber-sumber data yang ada. "Sumber-sumber tersebut di peroleh dari berbagai buku dan tulisan-tulisan lainnya dengan mengandalkan teori-teori yang ada untuk diitafsirkan secara jelas dan mendalam untuk menghasilkan skripsi dan antiskripsi."

Triangulasi menjadi cara yang digunakan oleh peneliti untuk menguji dan data yang didapat sehingga hasilnya dapat sesuai dengan maksud dan tujuan penelitian. Triangulasi data adalah teknik pemeriksaan data yang memanfaatkan sesuatu yang lain diluar data tersebut untuk keperluan pengecekan atau sebagai pembanding data tersebut. ${ }^{5}$ triangulasi dalam penelitian ini dilakukan dengan membandingkan dan mengecek derajat balik kepercayaan suatu informasi yang diperoleh dengan metode kualitatif.

\section{HASIL DAN PEMBAHASAN}

\section{Pertumbuhan Iman Anak}

Pertumbuhan menurut Kamus Besar Bahasa Indonesia berasal dari kata tumbuh yang memiliki arti timbul atau hidup dan bertambah besar atau sempurna, sedang

\footnotetext{
${ }^{4}$ Soejono and Abdurahman, Metode Penelitian Suatu Pemikiran Dan Penerapannya (Jakarta: Reneka Cipta, 1999). 25

${ }^{5}$ Lexy J Moleong, Metodologi Penelitian Kualitatif (Bandung: PT Remaja Rosdakarya Offset, 2007).330
} 
berkembang atau timbul sama denan terbit atau terjadi. Pertumbuhan pula bererti hal keadaan tumbuh, perkembangan atau kemajuan dan sebagainya. ${ }^{6}$

Menurut Kamus Besar Bahasa Indonesia iman adalah kepercayaan atau yang berkenaan dengan agama. Kepercayaan dan keyakinan kepada Allah, nabi, kitab, dan sebagainya. Ketetapan hati, keteguhan batin dan keseimbangan batin. ${ }^{7}$

Dan anak menurut Kamus Besar Bahasa Indonesia adalah keturunan atau manusia yang masih kecil. ${ }^{8}$

Sehingga dari literaur kata, kita dapat mengambil kesimpulan pertumbuhan iman dari anak ialah proses perkembangan keyakinan dan kepercayaan anak kepada Allah khususnya kepada Tuhan Yesus Kristus sehingga mencapai tahap sempurna dalam iman dan pengharapan kepada Allah.

\section{Pola Asuh Keluarga Kristen}

Dalam keluarga manapun pasti memiliki yang Namanya pola asuh. Begitu juga dengan keluarga Kristen jgua pola asuh adalah salah satu indikator penting. Pola asuh terdiri dari dua kata yaitu pola dan asuh. Dari literatu kata pola asuh dalam Kamus Besar Bahasa Indonesia kata pola berarti model, corak, potongan kertas, sistem, cara kerja, bentuk atau struktur yang tetap. Sedangkan kata asuh dapat berati memelihara, menjaga, merawat, mendidik, membimbing membantu, melatih anak kecil, dan memimpin atau mengepalai dan menyelenggarakan satu badan atau lembaga. ${ }^{9}$ Untuk lebih jelasnya, kata asuh adalah merangkumi segala aspek yang berkaitan dengan pemeliharaan, penjagaan, sokongan, dan bantuan sehingga orang tetap berdiri dan menjalani hidupnya secara sehat.

Ahmad Tafsir dalam Yatim-Irwanto mengatakan bahwa pola asuh adalah pendidikan, sedangkan pendidikan berarti bimbingan untuk perkembangan jasmani dan rohani, menuju terbentuknya kepribadian yang utama oleh anak didik dari pendidik. ${ }^{10}$ Singgih berpendapat bahwa cara yang lebih mudah untuk mempersiapkan anggota keluarga termasuk anak supaya dapat mengambil keputusan sendiri dan bertindak sendiri sehingga mengalami perubahan dari keadaan bergantung kepada orang tua menjadi berdiri sendiri dan bertanggung jawab sendiri adalah dengan sikap dan pola asuh orang tua.

${ }^{6}$ Tim Redaksi Kamus Besar Bahasa Indonesia, Kamus Besar Bahasa Indonesia, 3rd ed. (Jakarta: Balai Pustaka, 2007).

7 Ibid.

${ }^{8}$ Ibid.

${ }^{9}$ Depdikbud, Kamus Besar Bahasa Indonesia (Jakarta: Balai Pustaka, 1988).54

${ }^{10}$ Dani I Yatim and Irwanto, Kepribadian, Keluarga, Dan Karkotika : Tinjauan Sosial-Psikologis (Jakarta: Arcan, 1991). 94 


\section{Keluarga Kristen}

Keluarga adalah kelompok yang terdiri lebih dari satu individu. Secara khusus dapat kita simpulkan keluarga dalam UU 10 Tahun 1992 pasal 1 ayat 10 didalamnya terdapat ayah, ibu dan anak-anak atau suami, isteri dan anak-anaknya. ${ }^{11}$

Keluarga adalah dua orang atau lebih yang tinggal bersama dan terikat karena darah, perkawinan dan adopsi. Elisabeth B Hurlock, mengatakan "The familiy is the most important part of the child'social net work people, thing and life in general" 12 kalimat tersebut artinya bagian terpenting bagi anak dalam hubungan sosial masyarakat dan segala sesuatu dalam kehidupan pada umumnya adalah keluarga. Kita dapat menyimpulkan dari beberapa defenisi diatas bahwa bagian terkecil dalam masyarakat yang terdiri dari ayah, ibu atau suami, isteri dan anak karena adanya ikatan darah atau perkawinan dan dipelihara adalah keluarga.

\section{Pola Asuh Keluarga}

Pola asuh atau gaya asuh dalam keluarga memiliki dua elemen penting yaitu parental responsiveness atau respon orang tua dan parental demandingness atau tuntutan orang tua. Adapun gaya pola asuh ini adalah seperti berikut :

Pertama, Parental Responsiveness: yaitu orang tua secara sengayang secara sengaja dan mengatur dirinya sendiri untuk sejalan, mendukung dan menghargai kepentingan dan tuntutan anaknya. ${ }^{13}$

Kedua, Parental Demandingness: yaitu orang tua menuntut anaknya untuk menjadi bagian dari keluarga dengan pengawasan, penegakkan disiplin dan tidak segan memberi hukuman jika anaknya tidak menuruti. ${ }^{14}$ Selain respond tuntutan, gaya pola asuh juga ditentukan oleh faktor yang ketiga iaitu control psikologis iaitu menyalahkan, kurang menyayangi atau mempermalukan anak.

\section{Pentingnya Pertumbuhan Iman Anak}

Iman merupakan anugerah yang diberikan Allah itu sendiri kepada setiap orang percaya, dan sekarang tinggal bagaimana respon atau ketaatan orang percaya akan anugerah Allah itu. Maka berkaitan dengan itu, anak yang juga merupakan anggota tubuh Kristus oleh karena baptisannya perlu di bina serta diarahkan hingga mereka menjadi dewasa dalam iman dan mampu mengenal dirinya dan Tuhan secara benar. ${ }^{15}$

\footnotetext{
${ }^{11}$ Suratman Effendi, Fungsi Keluarga Dalam Meningkatkan Kualitas Sumber Daya Manusia Di Daerah Jambi (Jakarta: Departemen Pendidikan dan Kebudayaan, 1995).34

${ }^{12}$ Elizabeth B Hurlock, Child Development (McGraw: Hill Education, 1978).494

13 Agus Hermawan, "Pola Asuh Parental Responsiveness Dan Parental Demandingness Dalam Keluarga," INJECT (Interdisciplinary Journal of Communication) 3, no. 1 (2018): 105-123.109

${ }^{14}$ Ibid. 109

${ }^{15}$ E G Homrihgausen and I H Enklaar, Pendidikan Agama Kristen (Jakarta: BPK Gunung Mulia, 1989).
} $136-137$ 
Pengenalan tentang Tuhan kepada anak dimulai sejak kecil mengingat bahwa jiwa dan rohani anak sangat penting untuk mengalami pertumbuhan iman di dalam kehidupannya. Pengenalan sejak kecil akan menjadi menjadi penunjang dalam memasuki pengenalan akan hubungannya dengan Tuhan dan juga yang akan mendorongnya untuk mengetahui lebih jauh tentang keberadaan dirinya. Pengajaran Firman Tuhan kepada anak dapat menolong anak bertumbuh menjadi dewasa dalam iman dan kelak dapat menyikapi perubahan-perubahan sikap yang radikal dan kenyataan hidup imannya.

Dalam pertumbuhan anak orang tua harus memberikan penajaras dasar agama yang baik, sebab denang itu anak akan memiliki fondasi yang kokoh sebagai bagnunan Allah dan iman anak akan bertumbuh dalam kehidupannya sikap iman yang bagus itu akan tampak. Dalam Amsal 22: 6 dikatakan bahwa didikan yang diperoleh anak dari orang tua pada masa muda akan berperngaharuh terhadap kehidupan anak dikemudian hari. Orang tua harus mendidik anak dan mengarahkannya kepada jalan yang benar dan seharusnya dan menghasilkan pertumbuhan jasmani dan rohani anak.

\section{Hambatan Dalam Pertumbuhan Iman Anak Keterbatasan Orang Tua}

Kemampuan orang tua, baik itu dari pengetahuan dan dan juga ekonomi menjadi bagian yang mengikat satu dengan yang lainnya dan mempengaruhi orang tua dalam mendidik anak. Orang tua membutuhkan pengetahuan baik dalam agar tidak salah arah dalam mengarahkan anak menuju proses pendewasaan. Oleh karena itu orang tua harus memperlengkapi diri dengan baik terutama dari segi pengetahuan mengenai pola mendidik anak.

Keterbatasan diri harus disadari oleh orang tua dan mau membuka diri untuk belajar menjadi orang tua yang memiliki pengetahuan yang baik dalam mendidik anak-anaknya. Tentunya dasar dari semua itu adalah cintakasih orang tua kepada anak demi perkembangan masa depan anak tersebut.

Penting bagi orang tua mengetahui keterbatasannya, jia orang tua tidak mengetahui keterbatasannya hal ini dapat menjadi penghambat dalam tumbuh kembangnya seorang anak dengan baik dikarena kurang atau tidak adanya pola didik yang benar dalam keluarga. Agar dapat tumbuh dengan baik seorang anak harus dibekali dengan pola didik yang baik pula. Curahan perhatian orang tua yang membawa anak pada pengenalan akan Tuhan adalah pola didik yang baik. Pengenalan akan Tuhan adalah dasar dari segala sesuatu yang ada dalam kehidupan ini. Jika pengenalan akan Tuhan tercipta dengan baik maka ada penguasaan diri yang baik pula dalam pribadi orang tersebut.

\section{Kesibukan Orang Tua}

Kesibukan orang tua dapat menjadi masalah dalam keluarga. Ketika orang tua sudah tidak lagi bisa membagi waktu dengan anak-anaknya hal ini akan mempengaruhi 
pembentukan pribadi anak. Pertumbuhan yang seharusnya berdasarkan pengamatan orang tua sudah tidak lagi berfungsi dengan semestinya. Meskipun demikian, tidak bisa dimungkiri bahawa kesibukan orang tua oleh karena pekerjaan ( Karier ) juga semata-mata demi kepentingan keluarga termasuk kepentingan anak-anak (dalam hal keperluan ekonomi) hal tersebut menurut orang tua juga merupakan faktor yang penting. Namun pemahaman yang demikian perlu dipahami oleh orang tua bahwa ada sisi positif maupun negetifnya. Dari sudut pandang positif: kebutuhan keluarga ( termasuk anak-anak ) dapat terpenuhi. Tetapi jika dilihat dari sudut pandang negetif: apabila orang tua hanya terfokus pada karier atau pekerjaannya dibanding memberikan perhatian bagi anak-anaknya atau bahkan tidak ada waktu bagi anak, tentunya hal itu menjadi sebuah keprihatinan dalam keluarga tersebut, dimana anak akan merasa kurang mendapatkan kasih sayang atau bahkan tidak sama sekali. Hal ini tentunya menjadi sebuah dilema bagi si-anak karena kurangnya hubungan yang baik antara orang tua dan anak.

\section{Kurangnya Komunikasi}

Komunikasi antara anak dan orang tua sangat penting karena hal tersebut dapat mempengaruhi pertumbuhan iman anak. Kurangnya komunikasi orang tua dengan anak dapat menjadi faktor yang menghambat perkembangan iman anak. Bagaimana anak dapat mengenal Allah jika Allah dan kehendaknya tidak pernah diceritakan oleh orang tua kepada anak. Hal ini bisa saja terjadi dalam suatu keluarga apabila orang tua sudah tidak lagi memiliki waktu untuk berkomunikasi kepada anak. Komunikasi yang kurang juga dapat merusak keharmonis hubungan antara orang tua dan anaknya.

\section{Jenis-Jenis Pola Asuh}

Marcolm Hardy dan Steve Heyes berpendapat ada empat jenis pola asuh yang dilakukan orang tua dalam keluarga. Pertama, yaitu pola asuh Autokratis (otoriter). Pola asuh dengan aturan-aturan yang kaku dari orang tua dan kebebasan anak sangat di batasi. Kedua, pola asuh demokratis. Pola asuh yang bersifat terbuka antara orang tua dan anak. Ketiga, pola asuh permisif. Pola asuh yang memberikan kebebasan tanpa batas pada anak untuk berprilaku sesuai dengan keinginannya sendiri. Keempat Laissez faire. Pola asuh dengan sikap acuh tak acuh orang tua terhadap anaknya. ${ }^{16}$

Berikut penjabaran dari model-model pola asuh dimulai dari otoriter, demokrasi, permisif dan laissez faire:

\section{Pola Asuh Otoriter}

Menurut Stewart dan Koch pola asuh otoriter atau mengasuh anak dengan aturan aturan yang tegas, seringkali memaksa anak untuk berperilaku seperti dirinya (orang tua), anak dibatasi bertindak atak kehendanya sendiri. Dalam pola ini otoriter dipengaruhi oleh

\footnotetext{
${ }^{16}$ Malcolm Hardy, Steve Heyes, and Soenardji, Pengantar Psikologi (Jakarta: Erlangga, 1986).131
} 
sikap orang tua yang sealu menganggap semua sikapnya sudah benar, sehingga dalam pola ini orang tua menganggap pendapat anak tidak perlu dipertimbangkan sehingga komunikasi dan bertukar pikiran antara orang tua dan anak jarang terjadi dalam pola asuh ini. Hasil dari pola asuh ini dapat menghasilkan anak-anak yang memiliki kompetensi dan cukup bertanggung jawab, namun anak dari pola asuh ini juga memiliki kecenderungan menarik diri secara sosial anak menjadi kurang spontan dan tampak tidak memiliki kepercayaan diri yang baik. ${ }^{17}$

Orang tua yang mengasuh anak dengan pola asuh otoriter mempunyai ciri antara lain: kaku, tegas, suka menghukum, kurang ada kasih sayang serta simpati. Orang tua memaksa anak-anak untuk patuh pada nilai-nilai mereka, serta mencoba membentuk lingkah laku sesuai dengan tingkah lakunya serta cenderung mengongkong keinginan anak. Anak tidak diberi kesempatan ataupun mendapat dorongan dari orang tua untuk berdedikari dan jarang mendapat pujian dari orang tua. Hak anak dibatasi tetapi dituntut tanggung jawab seperti anak dewasa. Orang tua yang otoriter cenderung memberi hukuman terutama hukuman fisik.

\section{Pola Asuh Demokratis}

Pola asuh demokratis denan pola asuh ini orang tua memberikan pengakuan terhadap kemampuan anak, anak diberi kesempatan untuk tidak selalu tergantung pada orang tua. Dalam pola ini Pendapa anak didengarkan dan mendapatkan sedikit kebebasan untuk mengambil keputusan menentukan apa yang terbaik bagi dirinya. Anak juga dilibatkan dalam pembicaraan terutama yang menyangkut dengan kehidupan anak itu sendiri. Anak terlatih untuk bertanggung jawab kepada dirinya sendiri karena adanya kesempatan yang diberi untuk mengembangkan penguasaan dirinya. Anak dilibatkan dan diberi kesempatan untuk mengambil bahagian dalam mengatur hidupnya.

Dalam pola asuh demokratis hampir segala keperluan dasar anak dapat diberi dengan wajar. Jika keperluan dasar manusia terpenuhi maka akan hal itu akan menimbulkan suasana psikologi maupun sosial yang menggembirakan. Dalam pola asuh ini komunikasi dapat berjalan wajar dan lancar sehingga setiap persoalan yang dialami anak dalam keluarga dapat disalurkan dalam komunikasi. Dengan demikian, stress dan patah semangat dikalangan anak tidak muncul.

\section{Pola Asuh Permisif}

Pola asuh ini orang tua mendidik anak secara bebas, kelonggaran diberikan kepada anak seluas-luasnya untuk memilih apa yang mereka kehendaki karena anak dianggap sebagai orang dewasa atau muda. Bimbingak yang berarti bagi anak tidak cukup hal ini dkarenakan lemahnya control orang tua terhadap anak. Pola ini menganggap semua yang

${ }^{17}$ Siti Aisyah et al., "Perkembangan Dan Konsep Dasar Pengembangan Anak Usia Dini," in Hakikat Anak Usia Dini (Jakarta: Universitas Terbuka, 2014). 5 
dilakukan oleh anak adalah benar dan tidak perlu mendapatkan teguran, arahan atau bimbingan. Pola asuh permisif menanamkan sifat yakni anak dapat memegang ketetapan dan aturan dalam keluarga sehingga anak memperoleh pernanan untuk menentukan keputusan dalam keluarga. Orang tua memperbolehkan anak melakukan apa yang dia kehendaki. Orang tua menuruti segala kemauan anak. Anak cenderung bertindak sesuka hati, tanpa pengawasan orang tua.

Jenis orang tua yang mempunyai pola asuh permisif cenderung selalu memberikan kebebasan pada anak tanpa memberikan pengawasan sama sekali. Anak sedikit sekali dituntut untuk suatu tangung jawab, tetapi mempunyai hak yang sama seperti orang dewasa. Anak diberi kebebasan untuk mengatur dirinya sendiri dan orang tua tidak banyak mengatur anaknya. Orang tua permisif lemah sekali dalam mendisiplinkan anak dan anak selalu bertindak sesuai dengan kehendaknya.

\section{Pola asuh Laissez faire}

Pola asuhan ini memiliki kesamaan dengan pola asuh yang sebelumnya dimana kebebasan tanpa batas pada anak untuk berperilaku sesuai dengan keinginannya sendiri. tidak ada aturan dan pengarahan yang diberikan orang tua kepada anak. Dalam pola asuh ini anak bebas mengambil keputusan apapun tanpa pertimbangan dari orang tua. Dengan demikan benar atau buruknya perilakau ataupun keputusan yang diambil oleh anak tidak akan diketahui anak itu sendiri karena orang tua tidak pernah membenarkan ataupun menyalahkan anak. Pola ini mengakibatkan anak akan berprilaku sesuai dengan keinginanya sendiri, tidak peduli apakah hal itu sesuai dengan norma masyarakat atau tidak. Yang membedakan pola ini dengan pola sebelumnya ialah Pada pola asuh ini anak dipandang sebagai makhluk hidup yang berpribadi bebas sehingga pola ini tidak memiliki sedikitpun kontrol kepada anak sedangkan pola pesimis menganggap anak dewasa sehingga lemahnya kontrol dari orang tua. Bagi pola ini anak adalah subjek yang dapat bertindak dan berbuat menurut hati nuraninya. Orang tua membiarkan anaknya mencari dan menentukan sendiri apa yang diinginkannya. Kebebasan sepenuhnya diberikan kepada anak. Orang tua seperti ini cenderung kurang perhatian dan acuh tak acuh terhadap anaknya.

\section{Tugas Dan Tanggung Jawab Orang Tua Kristen}

Menanamkan nilai-nilai kekristianan dalam keluarga merupakan peranan penting

orang tua. Tak bisa disangkal bahwa penanaman nilai-nilai atau keutamaan kekristianan bermula dari keluarga. Dengan kata lain tingkah laku seseorang sebagai orang Kristian dilandasi oleh pendidikan yang baik dalam keluarganya. Peran merupakan bagian vital dalam keluarga sebab perubahan arah atau nilai-nilai kehidupan setiap individu ditentukan oleh sejauh mana setiap pribadi mendapat didikan dalam keluarganya. Contoh yang baik dalam pertumbuhan anak didapatkan nya dengan melihat keteladanan orang tua, oleh 
karena itu orang tua harus memberikan keteladanan yang baik bagi anak-anaknya melalui sikap dan tindakan orang tua dalam kesehariannya, sehingga keteladanan itu menghasilkan pertumbuhan yang baik bagi anak. Keadaan keluarga yang seha dan harmonis akan berdampak bagik bagi jasmani maupun spiritual anak.

Kedewasaan iman seseorang tidak terjadi dalam suatu proses yang alamiah. Sebagai orang percaya kita memiliki keyakin bahwa Roh Kudus memiliki peranan didalam proses kedewasaan iman. Allah sendiri yang telah menganugerahkan iman itu kepada kita sebagai orang percaya, setelah itu bagian dari kita yaitu bagimana sikap kita terhadap anugerah Allah. Maka orang tua memiliki tanggung jawab dalam mandat Allah, orang tua harus memahami bahwa ia memiliki tanggung jawab atas pertumbuhan iman anak-anaknya menuju kedewasaan. Anak dalam baptisannya menjadikannya anggota tubuh Kristus oleh karena itu anak perlu dibina serta diarahkan sampai mereka menjadi manusia yang dewasa dalam iman maupun dalam pengenalan akan dirinya sendiri dan Tuhan secara benar. ${ }^{18}$

\section{KESIMPULAN}

Pola asuh yang seimbang ditandai dengan adanya penghargaan terhadap individualitas akan tetapi didalamnya juga menekankan perlunya aturan dan pengaturan. Didalam pola asuh yang baik terdapat integritas, otoritas dan percaya diri, namun terdapat juga sikap untuk menghargai pendapat, minat dan keputusan anak serta perbedaan kepribadian. Cinta kasih orang tua kepada anak akan menjadi karakter dari pola asuh yang digunakan. Orang tua dengan pola asuh yang baik, dia akan mengasuh dengan penuh cinta kasih. Pola asuh yang baik mudah memerinci tetapi menuntut tingkah laku yang baik. Aturan dalam keluarga tetap harus dijaga sifat integritas dan tegas harus dimiliki oleh orang tua untuk menjaganya. Orang tua dalam pola asuh yang baik juga harus bersedia memberi hukuman untuk menjaga aturan tersebut namun hukuman itu dalam keadaan yang ringan dan situasi yang hangat dalam hubungan oran tua dan anak. Oleh karena itu dalam pola asuh yang baik orang tua dan anak harus saling mendukung. Dalam hubungan pola asuh orang tua dan anak menjelaskan semua tindakan pendisiplinan yang digunakan dilakukan dengan keterbukaan dan kesepakatan anatar orang tua dan anak.

Era globalisasi memang telah mengubah segalanya. Kemajuan jaman juga berdampak pada gaya hidup manusa secara global. Persaingan hidup kian lama semakin berat, terkadang persaingan yang berat itu berdampak terhadap sikap orang tua dalam keluarga. Demi memenuhi tanggung jawab dalam keluarga terkadang orang tua lupa memberikan perhatian dalam keluarga. Sehingga focus dari orang tua lebih terarah kepada hal-hal yang bersifat memenuhi nafkah dari pada perhatian kepada anak. Kemajuan teknologi juga merupakan bagian dari hidup yang dijalani oleh anak dan memiliki dampak tersendiri bagi anak, bila tidak ada pengawasan dan bimbingan yang cukup baik akan menjadi buruk bagi pertumbuhan anak. Oleh karenanya, sejak dini pada anak perlu

\footnotetext{
${ }^{18}$ Homrihgausen and Enklaar, Pendidikan Agama Kristen. 136-137
} 
ditanamkan nailai-nilai moral sebagai pengatur sikap dan perilaku individu dalam melakukan interaksi sosial di lingkungan keluarga, masyarakat maupun bangsa. Oleh karena itu orang tua mempunyai tugas yang tidak boleh dilalaikan. Orang tua sebagai penuntun dan teladan bagi anak-anak. Tugas orang tua seperti ini merupakan suatu pelayanan yang bertujuan bukan untuk kepentingan anak-anak saja, melainkan terutama untuk memuliakan nama Tuhan.Pemahaman dalam orangtua mengenai pola asuh keluarga Kristen terhadap pertumbuhan iman anak ialah memahami bahwa keluarga merupakan wadah utama pertumbuhan iman anak, orang tua harus sering mendidik anak dengan kasih Allah, orangtua harus menjadi teladan bagi anak, orangtua dan anak harus bersama-Sama bertumbuh di Gereja. pemahaman mengenai konsep maupun pelaksanaan tentang pertumbuhan iman anak adalah pola yang diberikan orang tua dalam mendidik atau mengasuh anak baik secara langsung maupun tidak secara langsung. Cara mendidik secara langsung artinya bentuk asuhan orang tua yang berkaitan dengan pembentukan kepribadian, kecerdasan dan ketrampilan yang dilakukan secara sengaja, baik berupa perintah, larangan, hukuman, penciptaan situasi maupun pemberian hadiah sebagai alat pendidikan.

\section{KEPUSTAKAAN}

Aisyah, Siti, Mukti Amini, Titi Chandrawati, and Dian Novita. "Perkembangan Dan Konsep Dasar Pengembangan Anak Usia Dini." In Hakikat Anak Usia Dini. Jakarta: Universitas Terbuka, 2014.

Depdikbud. Kamus Besar Bahasa Indonesia. Jakarta: Balai Pustaka, 1988.

Effendi, Suratman. Fungsi Keluarga Dalam Meningkatkan Kualitas Sumber Daya

Manusia Di Daerah Jambi. Jakarta: Departemen Pendidikan dan Kebudayaan, 1995.

Gunarsa, Singgih D. Psikologi Perkembangan Anak Dan Remaja. Jakarta: BPK Gunung Mulia, 1991.

Hardy, Malcolm, Steve Heyes, and Soenardji. Pengantar Psikologi. Jakarta: Erlangga, 1986.

Hermawan, Agus. "Pola Asuh Parental Responsiveness Dan Parental Demandingness Dalam Keluarga.” INJECT (Interdisciplinary Journal of Communication) 3, no. 1 (2018): 105-123.

Homrihgausen, E G, and I H Enklaar. Pendidikan Agama Kristen. Jakarta: BPK Gunung Mulia, 1989.

Hurlock, Elizabeth B. Child Development. McGraw: Hill Education, 1978.

Indonesia, Tim Redaksi Kamus Besar Bahasa. Kamus Besar Bahasa Indonesia. 3rd ed. Jakarta: Balai Pustaka, 2007.

Moleong, Lexy J. Metodologi Penelitian Kualitatif. Bandung: PT Remaja Rosdakarya Offset, 2007.

Pearlman, Myer. Penyelidikan Anak. Malang: Gandum Mas, 1940.

Simanjuntak, Fredy. "MENGUAK RAHASIA PRIBADI ABRAHAM ATAS KUALITAS KEIMANANNYA PADA ALLAH BAPA.” Real Didache 1, no. 2 (April 16, 2016):

73-94. https://doi.org/10.31227/osf.io/43fj7.

Soejono, and Abdurahman. Metode Penelitian Suatu Pemikiran Dan Penerapannya. 
Jakarta: Reneka Cipta, 1999.

Yatim, Dani I, and Irwanto. Kepribadian, Keluarga, Dan Karkotika : Tinjauan SosialPsikologis. Jakarta: Arcan, 1991. 